\title{
ПОЧЕМУ А. МЕРКЕЛЬ ОТКАЗАЛАСЬ ОТ ПОСТА ПРЕДСЕДАТЕЛЯ ПАРТИИ ХДС
}

\begin{abstract}
Аннотация. В статье подробно анализируются причины, побудившие канилера ФРГ А. Меркель не выдвигать свою кандидатуру на пост председателя партии ХДС, которую она возглавляла на протяжении 18 лет. Автор подробно разбирает шансы и риски принятого решения для сохранения канилерства А. Меркель. Проводит связь между внутриполитической ситуацией в Германии и партийно-политическим развитием ХДС.

Ключевые слова: партийно-политическая система, ФРГ, демократия, канилер, А. Меркель, ХДС, ХСС, председательство, политическая конкуренщия, демократия, политическая элита.
\end{abstract}

Ангела Меркель - политический долгожитель, её стремительная и неожиданная для многих карьера - результат не только внутриполитического развития Германии после объединения, но и феномен, выходящий за пределы немецкого государства. Первая женщина канцлер, первая глава правительства ФРГ с «гэдээровским» прошлым, признанная лидер Европейского союза, авторитетный политик международного уровня. Она четыре раза подряд становилась канцлером, 18 лет возглавляла самую сильную немецкую политическую партию Христианско-демократический союз (ХДС), успехи которой были и остаются во многом её личной заслугой, впрочем, как и поражения.

Секрет формулы успеха «железной канцлерин» пытаются объяснить многие. Физик по образованию, она умеет просчитывать ситуации и прорабатывать в уме множество различных сценариев, обладает огромным терпением и, по мнению критиков, медлительна в принятии решении. Ждёт, когда неприемлемые варианты отпадут сами собой, а политические конкуренты устанут и совершат ошибку. По признанию самой А. Меркель, оставаться на протяжении 13 лет главным человеком в государстве ей помогало совмещение постов канцлера и председателя партии. Именно сосредоточение этих двух функций в одних руках позволяет наиболее эффективно управлять страной: контролировать благодаря поддержке партии нижнюю палату парламента, тем самым способствуя принятию законов, которые разрабатывает возглавляемое ею правительство. К тому же пост председателя партии обеспечивает надёжный тыл - чтобы сместить канцлера до выборов, две трети депутатов бундестага должны договориться о кандидатуре нового лидера, который без поддержки однопартийцев действующего главы правительства не сможет набрать необходимое количество голосов для выражения вотума конструктивного недоверия. Провести такую операцию за спиной канцлера председателя партии довольно сложно.

Совмещение двух постов - главы правительства и партии не является личным открытием А. Меркель. Эту опцию использовали и другие лидеры Германии, например, бывший председатель СДПГ Г. Шрёдер. Канцлерин не раз признавалась журналистам, что именно по-

\footnotetext{
(C) Тимошенкова Екатерина Петровна - кандидат исторических наук, ведущий научный сотрудник, заместитель руководителя Центра германских исследований ИЕ РАН. Адрес: 125009, Россия, Москва, ул. Моховая, д. 11, стр. 3.E-mail: katerinatim@mail.ru.

DOI: http://dx.doi.org/10.15211/vestnikieran620189
} 
литическое падение её предшественника произвело на неё сильное впечатление и стало уроком. По мнению А. Меркель, деградация авторитета канцлерской власти Г. Шрёдера началась с момента его отказа от поста председателя партии из-за дебатов по поводу принятия социалдемократами непопулярной у населения программы «Агенда 2010». По этой причине её заявление 29 октября 2018 г. о том, что она не будет выдвигать свою кандидатуру на пост председателя ХДС на следующем съезде партии, прозвучало как политическая сенсация ${ }^{1}$. Многие журналисты заговорили об окончании эры Меркель и её скором уходе с поста канцлера. Хотя сама канцлерин подчеркнула, что намерена продолжить возглавлять правительство до окончания легислатурного периода. При этом она пообещала общественности завершить свою политическую карьеру после 2021 г. - она не будет выдвигать свою кандидатуру на пост канцлера в пятый раз, не станет возглавлять международные организации или влиятельную европейскую структуру, не увидят её в качестве депутата и в новом созыве бундестага 2 .

Для тех, кто внимательно следит за выступлениями канцлерин, заявление о том, что она возглавляет правительство ФРГ в последний раз, сюрпризом не стало. В беседах с журналистами лидер ХДС как-то призналась, что политикой должны заниматься профессионалы, и 10 лет - это наиболее эффективный и оптимальный срок для политической карьеры на высшем государственном уровне ${ }^{3}$. По истечении этого времени трудно удерживать авторитет. Поэтому уходить нужно вовремя и, следуя её логике, самой. Однако несмотря на эти рассуждения, А. Меркель удаётся быть первой уже 13 лет. Накануне выборов в бундестаг в сентябpe 2017 г. она пообещала избирателям, что в случае победы ХДС, этот срок канцлерства станет для неё последним, а также призналась, что решение идти в четвёртый раз на выборы оказалось самым сложным в её политической карьере. Меркель понимает, что не все её решения находят поддержку в обществе и слышит позицию тех, кто выступает против её политики, однако чувствует большую ответственность перед страной и поэтому готова быть канцлером ещё один легислатурный период.

Что же заставило «тефлоновую леди» спустя год после победы на выборах принять столь рискованное, с её точки зрения, решение - отказаться от принципа совмещения двух должностей: правительственной и партийной? Сможет ли она, не будучи председателем ХДС, оставаться на посту канцлера, не опасаясь бунта в рядах собственной партии? И почему она выступила с этим заявлением 29 октября 2018 г.?

Причин, побудивших А. Меркель принять такое решение несколько. Главная, на наш взгляд, это кризисное состояние правительства, которое она возглавляет. В своём выступлении канцлерин честно признала, что то, как работает Большая коалиция в Берлине неприемлемо. Правительство находится в кризисе с момента образования. И хотя управлять коалицией, состоящих из партий ХДС, ХСС и СДПГ, для А. Меркель привычное дело, отличительной особенностью нового кабинета стало не столько вынужденное участие партнёров (образование Больших коалиций - всегда вынужденный шаг для двух народных партий ХДС/ХСС и СДПГ), сколько их обречённость на принятие решения о формировании правительства. Результаты федеральных выборов 2017 г. в нижнюю палату германского парламента оказались для этих партий гораздо ниже ожидаемых.

Учитывая популярность право-популистской партии «Альтернатива для Германии», их можно рассматривать, как вотум недоверия избирателей к прошлому правительству А. Меркель. Поэтому она постаралась уйти от надоевшего немецким гражданам союза народных

\footnotetext{
${ }_{1}^{1}$ Съезд партии ХДС состоялся 7 декабря в Гамбурге. Прим. авт.

2 «Merkel will nicht mehr für Parteivorsitz kandidieren». URL: http://www.spiegel.de/politik/deutschland/cdu-angelamerkel-will-nicht-mehr-fuer-parteivorsitz-kandidieren-a-1235646.html (дата обращения: 20.12.18).

${ }^{3}$ Nikolaus Blome. Angela Merkel - Die Zauderkünstlerin. Pantheon Verlag, München 2013. S. 51.
} Научно-аналитический вестник ИЕ РАН, 2018, №6 
Итоги выборов в бундестаг 24 сентября 2017 г.

\begin{tabular}{|l|c|c|c|c|c|c|c|}
\hline Партия & $\begin{array}{c}\text { Первые } \\
\text { голоса, \% }\end{array}$ & $\begin{array}{c}\text { Первые голоса, } \\
\text { изменение в срав- } \\
\text { нении с 2013, \% }\end{array}$ & $\begin{array}{c}\text { Прямые } \\
\text { мандаты }\end{array}$ & $\begin{array}{c}\text { Вторые } \\
\text { голоса, \% }\end{array}$ & $\begin{array}{c}\text { Вторые голоса, из- } \\
\text { менение в сравнении } \\
\text { с 2013, \% }\end{array}$ & $\begin{array}{c}\text { Всего } \\
\text { мест }\end{array}$ & $\begin{array}{c}\text { Всего мест, из- } \\
\text { менение в сра- } \\
\text { нении с 2013 }\end{array}$ \\
\hline ХДС & 30,2 & -7 & 185 & 26,8 & $-7,4$ & 200 & -55 \\
\hline СДПГ & 24,6 & $-4,8$ & 59 & 20,5 & $-5,2$ & 153 & -40 \\
\hline АДГ & 11,5 & 9,6 & 3 & 12,6 & 7,9 & 94 & 94 \\
\hline СвДП & 7 & 4,6 & 0 & 10,7 & 6 & 80 & 80 \\
\hline Левые & 8,6 & 0,3 & 5 & 9,2 & 0,6 & 69 & 5 \\
\hline Зелёные & 8 & 0,7 & 1 & 8,9 & 0,5 & 67 & 4 \\
\hline ХСС & 7 & $-1,1$ & 46 & 6,2 & $-1,2$ & 46 & -10 \\
\hline
\end{tabular}
https://www.wahlrecht.de/news/2017/bundestagswahl-2017.html ${ }^{1}$

партий и приняла решение вести переговоры о создании совершенно новой коалиции, состоящей из ХДС/ХСС, СвДП и «Союза 90/Зелёные». Успех «АдГ», которая оказалась третьей си-лой по итогам избирательной кампании, не позволил этаблированным партиям создать привычную комбинацию по формуле: победитель выборов плюс младший партнёр. Договориться с большим количеством игроков, которые шли на выборы с взаимоисключающими обеща-ниями, не удалось. К тому же никто из них не хотел помогать А. Меркель выйти из сложной ситуации ценой потери своей популярности у избирателей. Отрицательное влияние на желание потенциальных партнеров по коалиции участвовать в правительстве А. Меркель оказал её стиль управления. И социал-демократы и либералы по окончании легислатурных периодов теряли голоса на следующих выборах, т. к. все их успехи становились достижениями канцлерин, а трудности, которые испытывали коалиции - результатом плохого взаимодействия младшего партнёра с ХДС.

За время пребывания у власти А. Меркель оказалась самым противоречивым политиком. Решение о принятии большого числа беженцев в Германии раскололо немецкое общество пополам и способствовало росту популярности право-популистской «Альтернативы для Германии», которая отобрала голоса у других партий, чем повергла их в шоковое состояние и вынудила начать пересматривать свои программы и стратегии. Оттачивать политический профиль и восстанавливать доверие избирателей легче в оппозиции - не надо нести ответственность за непопулярные решения правительства. Провал первого раунда переговоров о создании коалиции с СвДП и «зелёными» грозил немецким партиям новыми выборами, резуль-таты которых могли значительно ослабить их прежние позиции и усилить «АдГ». Для Герма-нии такая нестабильность в вопросе управления могла превратиться в раздражающий фактор, последствия которого трудно просчитать и контролировать с учетом тенденции поправения настроений электората. Необходимость постоянно отвлекаться на решение проблем дома ос-лабляла позиции Германии на международной арене и могла привести к потере лидерства в Европейском союзе. Вероятно, поэтому А. Меркель пришла к выводу, что слабое правительство лучше, чем никакое, и решилась на подписание компромиссного коалиционного соглашения, состоящего из уступок, как социал-демократам, так и партии-союзнику XCC.

Коалиционное соглашение, подписанное 8 февраля 2018 г., спустя 4 месяца после выборов, превратилось после вступления его в силу в марте 2018 г. в пороховую бочку для её участников. При этом главным разжигателем конфликтов стал бывший союзник А. Мекрель, председатель баварской партии ХСС Х. Зеехофер, который активно критиковал миграцион-

\footnotetext{
${ }^{1}$ Vorläufiges Ergebnis der Bundestagswahl 2017 - Sitzverteilung. URL: https://www.wahlrecht.de/news/2017/ bundestagswahl-2017.html (дата обращения: 20.12.18).
}

Научно-аналитический вестник ИЕ РАН, 2018, №6 
ную политику канцлерин до и во время выборов в бундестаг. В качестве уступки он получил пост министра внутренних дел. Этот вынужденный шаг оказался роковым для А. Меркель и будущего новой коалиции. Войдя в состав правительства, Х. Зеехофер начал использовать своё назначение не только для внесения корректив в правительственный курс по вопросу приёма беженцев, но и для решения своих личных задач. Как глава партии ХСС, которой в сентябре 2018 г. предстояли земельные выборы в Баварии и борьба за электорат с право-популистской «АдГ», он сделал ставку на ужесточение миграционного законодательства и решил показать, «кто в доме хозяин». Спор между политиками достиг апогея в начале июня, когда Х. Зеехофер поставил А. Меркель ультиматум и дал ей для реализации компромисса всего две недели. Острота ведения спора и предмет (речь шла о высылке на границе Германии беженцев, которые уже зарегистрировались в других государствах ЕС) показывает, на наш взгляд, что главной движущей силой действий и заявлений баварского политика было желание поколебать авторитет А. Меркель и, вероятно, приблизить окончание ее политической карьеры, как канцлера. Разлад в коалиции повредил имиджу ХCC, она не сумела одержать внушительную победу на выборах в Баварии, потеряв много голосов в пользу «Союза 90/Зелёные» и «А Г ${ }^{1}$.

Фактически работа правительства с момента его образования проходила по одному сценарию: сначала жёсткий спор между традиционными союзниками ХДС и ХСС, поиск компромисса между ними, затем возмущение и угроза выхода из коалиции со стороны их партнёров социал-демократов, которых не устраивает отхождение от коалиционного договора и обсуждение нового решения без их участия. А. Меркель из эффективного менеджера превратилась в пожарного. При этом каждый новый конфликт, который разгорался между участниками правительственной коалиции, мог привести к её распаду. Вероятность того, что ей удастся сохранить за собой канцлерство до 2021 г., оказалась зыбкой. Выступая 29 октября 2018 г. перед коллегами по партии, А. Меркель призналась, что решение не выдвигать свою кандидатуру на пост председателя ХДС, она приняла ещё летом, однако надеялась объявить об том позже. Причиной, побудившей сделать заявление раньше, стали плохие результаты ХДС на земельных выборах в Гессене 2 . Падение популярности партии среди избирателей - результат влияния правительственного кризиса в Берлине, который А. Меркель не смогла преодолеть. Этот шаг с одной стороны демонстрирует обществу, что она осознаёт свою ответственность за снижение популярности партии, которую возглавляет, с другой - понимает: сложности с коалицией, которая может распасться в любой момент, требуют от неё повышенного внимания к своим первоочередным обязанностям главы правительства.

Спорная миграционная политика, курс ХДС на завоевание середины общества, приведший к её социал-демократизации и отходу от традиционных консервативных ценностей, принятие единоличных и неожиданных для базиса партии решений, особый стиль управления и объективная усталость от руководства А. Меркель привели к росту недовольства внутри Христианского демократического союза. Пока партия убедительно выигрывала выборы, ей удавалось контролировать внутреннюю оппозицию и сдерживать возмущение. Отказываясь от поста председателя партии и подтвердив публично, что четвёртое канцлерство станет для неё последним, А. Меркель предприняла попытку успокоить внутреннюю оппозицию среди хри-

\footnotetext{
${ }^{1}$ ХСС набрала на выборах в Баварии 37,2\% голосов, потеряв 10,4 процентных пункта. Landtagswahl 2018 in Bayern -Vorläufiges Ergebnis. URL: https://www.wahlrecht.de/news/2018/landtagswahl-bayern-2018.html\#absolut (Дата обращения: 20.12.18).

2 ХДС набрала на выборах в Гессене 26,9\% голосов, потеряв 11,35 процентных пункта. Landtagswahl 2018 in Hessen -Vorläufiges Ergebnis. URL: https://www.wahlrecht.de/news/2018/landtagswahl-hessen-2018.html (Дата обращения: 20.12.18).
} 
стианских демократов и предоставила себе возможность повлиять на выбор преемника, пока ещё обладает авторитетом и остаётся канцлером. Она уступает лидерство в партии, чтобы вернуть к себе доверие как к лидеру страны. Жертвует меньшим, чтобы сохранить большее. На наш взгляд, она прекрасно понимала, что данный шаг вызовет уважение со стороны коллег и конкурентов, которые, соблюдая правила политической корректности, будут вынуждены вспомнить её заслуги как председателя партии и выразить ей публичное уважение, что будет способствовать укреплению её авторитета. К тому же, взяв ответственность за неудачи ХДС на себя, она продемонстрировала образец политического мужества своим оппонентам, и прежде всего X. Зеехоферу, который долго держался за пост главы ХCС, но под давлением коллег по партии был вынужден последовать её примеру. Важно понимать, что решение А. Меркель призвано спасти её канцлерство в труднейшей внутриполитической ситуации, хотя оно может оказаться роковым и ускорить её падение с политического олимпа.

Таким образом, уход А. Меркель с поста председателя Христианского демократического союза после 18 лет руководства открывает для партии и Германии новую главу. Выбор преемника - это не только начало процесса обновления партийно-политической элиты, определение направления, в котором будет развиваться в будущем партия, это борьба за наследство А. Меркель и будущее канцлерство. И хотя в немецком законодательстве нет юридической нормы, обязывающей председателя партии выдвигать свою кандидатуру на пост канцлера, всем понятно, что у нового главы ХДС будет выбор, возможность и очень высокие шансы на победу.

\section{Список литературы}

Германия 2017 // Доклады Института Европы №354, отв. ред. В.Б. Белов, Москва, 2018, 139 c.

Европа 2017: партии, выборы, власть // Доклады Института Европы №353, отв. ред. В.Я. Швейцер, Москва, 2018, 129 с.

\section{References}

Germania 2017 // Doklady Instituta Ewropy №354, otv. red. V.B. Belov, Moskva, 2018, 139 s.

Evropa 2017: partii, vybory, vlast // Doklady Instituta Evropy № 353, otv. red. V. Ja Shwejzer, Moskwa, 2018, 129 s.

Nikolaus Blome. Angela Merkel - Die Zauderkünstlerin. Pantheon Verlag, München 2013/

Merkel will nicht mehr für Parteivorsitz kandidieren. URL: http://www.spiegel.de/politik/ deutschland/cdu-angela-merkel-will-nicht-mehr-fuer-parteivorsitz-kandidieren-a-1235646.html.

Es ist vorbei. URL: https://www.zeit.de/2018/45/angela-merkel-cdu-parteivorsitz-bundeskanz lerin-grosse-koalition-politisches-ende.

Kanzlerin Merkel will nicht mehr für Parteivorsitz kandidieren. URL: https://www.stern.de/ politik/deutschland/bundeskanzlerin-angela-merkel-will-nicht-mehr-fuer-parteivorsitz-kandidieren8422758.html.

Merkel will nur noch bis 2021 Kanzlerin bleiben. URL: https://www.nzz.ch/international/ merkel-will-nicht-mehr-fuer-den-cdu-parteivorsitz-kandidieren-ld.1431952. 


\section{Why Merkel refused the post of Chairman of the CDU Party}

Author. Ekaterina Timoshenkova, Candidate of Sciences (History), Leading Research Associate, Deputy Head of Center for German Studies, Institute of Europe, Russian Academy of Sciences. Address: 11-3, Mokhovaya str., Moscow, Russia, 125009. E-Mail: katerinatim@mail.ru.

Abstract. The article analyzes in detail the reasons that prompted Chancellor Merkel not to nominate her candidacy for the post of Chairman of the CDU party, which she headed for 18 years. The author analyzes in detail the chances and risks of the decision to preserve the Chancellor Merkel. He draws a link between the internal political situation in Germany and the party-political development of the CDU.

Keywords: party-political system, Germany, democracy, Chancellor, A. Merkel, CDU, CSU, presidency, political competition, democracy, political elite.

DOI: http://dx.doi.org/10.15211/vestnikieran620189 